\title{
Mobilization of seed storage proteins is crucial to high vigor in common bean seeds
}

\section{Natalia Carolina Moraes Ehrhardt-Brocardo ${ }^{1}$ Cileide Maria Medeiros Coelho $^{1^{*}(\mathbb{D})}$}

'Programa de Pós-graduação em Produção Vegetal, Universidade do Estado de Santa Catarina (UDESC), 88520-000, Lages, SC, Brasil. E-mail: cileide.souza@udesc.br. "Corresponding author.

ABSTRACT: Seed germination is a complex process controlled by many factors, in which physical and biochemical mechanisms are involved and the mobilization of reserves is crucial for this process to occur. Although, seed reserve mobilization is usually thought to be a postgermination process, seed reserve proteins mobilization occurs during germination. This study quantified seed proteins of bean genotypes during different hydration times, in order to understand the process of protein mobilization and whether there is relationship of this biochemical component with seed vigor. This study was conducted using seeds with different levels of vigor, genotypes with highest $(13,42,55$ and 81$)$ and lowest (07, 23, 44, 50, IPR-88-Uirapurú and Iapar 81) physiological quality. High vigor genotypes showed greater efficiency in hydrolysis and mobilization of protein component, because they presented low globulins content in cotyledons at radicle protrusion in relation to low vigor genotypes (07, 23 and 50). The protein alpha-amylase inhibitor, observed in all genotypes, is involved with the longer time needed for radicle protrusion, according to the band intensity difference in genotypes 07, 44 and Iapar 81.

Key words: Phaseolus vulgaris, genetic diversity, landrace genotypes, $1 D$ SDS-PAGE, mass spectrometry.

Mobilização das proteínas de reserva é crucial para o alto vigor em sementes de feijão

RESUMO: A germinação de sementes é um processo complexo controlado por muitos fatores, nos quais mecanismos físicos e bioquímicos estão envolvidos e a mobilização de reservas é decisiva para que esse processo ocorra. Embora a mobilização de reservas de sementes seja considerada um processo pós-germinativo, a mobilização das proteínas de reserva de sementes ocorre durante a germinação. Este estudo teve como objetivo quantificar as proteinas de sementes de genótipos de feijão durante os diferentes tempos de hidratação, a fim de compreender o processo de mobilização proteica e se há relação desse componente bioquímico com o vigor das sementes. Este estudo foi realizado utilizando sementes com diferentes níveis de vigor, genótipos com maior (13, 42, 55 e 81) e menor (07, 23, 44, 50, IPR-88-Uirapurú e Iapar 81) qualidade fisiológica. Os genótipos de alto vigor apresentaram maior eficiência na hidrólise e mobilização do componente proteico, pois apresentaram baixo teor de globulinas nos cotilédones na protrusão radicular em relação aos genótipos de baixo vigor (07, 23 e 50). A proteína inibidora da alfa-amilase, observada em todos os genótipos, está envolvida com o maior tempo necessário para a protrusão da radícula, de acordo com a diferença de intensidade da banda nos genótipos 07, 44 e Iapar 81.

Palavras-chave: Phaseolus vulgaris, diversidade genética, genótipos crioulos, ID SDS-PAGE, espectrometria de massas.

\section{INTRODUCTION}

Seed germination refers to the physiological process starting with the uptake of water by the dry seed and ending with the radicle protrusion. In orthodox seeds, with a resumption of water uptake, events such as mobilization of stored reserves are associated with seedling growth. All of the components for resumption of protein synthesis upon imbibition are present within the cells of mature dry embryos (BEWLEY, 1997). The germination process can be divided into three phases based on the water uptake pattern. Phase I is characterized by rapid imbibition (LOPES et al., 2013), repair of DNA damage and resumption of respiration and metabolism (HAN et al., 2013). Phase II is a plateau phase in which mitochondria synthesis and translation of stored mRNA occur, it is also regarded as a metabolism active phase during which reserves mobilization is initiated. Phase III is the postgermination stage stating with the radicle protrusion. Mobilization of reserves is one of the most critical events in germination, which could provide not only precursors but also energy for the biosynthetic processes (HAN et al., 2013).

Plants accumulate storage during seed development, in the middle and late maturation stages when seeds act as nitrogen sinks in the plant (MÜNTZ et al., 2001). These protein reserves are essential for seed germination and seedling establishment (ERBAŞ et al., 2016; GOYOAGA et al., 2011); GU et al., 2016) and they are determining 
features for the propagation of plant species, which are of both economic and ecologic importance (RAJJOU et al., 2012). Firstly, seed storage proteins are hydrolyzed to amino acids by active components called proteolytic enzymes. Amino acids may remain in the storage tissue; however, most are translocated to the developing embryonic axis tissues being used for the synthesis of enzymes and structural proteins (ROSENTAL et al., 2014).

The first classification used to define classes of seed storage proteins (SSP) was empirically developed by OSBORNE (1924), and grouped SSP based on their solubility in water (albumins), dilute salt solutions (globulins), aqueous alcohols (prolamins), and extractable by weakly acidic or alkaline or dilute SDS solutions (glutelins) (CHÉREAU et al., 2016). Globulins are the most abundant group of seed storage proteins in beans. They can be divided into two groups based on their sedimentation coefficients, $7 \mathrm{~S}$ vicilin-type globulins and $11 \mathrm{~S}$ legumin-type globulins, with molecular weight subunits ranging from 10 to $70 \mathrm{kDa}$ and 20 to $50 \mathrm{kDa}$, respectively (FREITAS et al., 2000).

Studies of landrace genotypes seeds originating at the Bean Active Germplasm Bank (BAF) at the Santa Catarina State University showed differences between genotypes from physiological seed quality (EHRHARDT-BROCARDO \& COELHO, 2016). The characterization of the physiological potential of landrace bean genotypes seeds, the intrinsic capacity of bean genotypes to behave differently, thus causing different responses among genotypes, allows assessment of the effect of genotype on seed vigor. Because of this genetic diversity, it suggested a greater possibility of finding an association between seed storage proteins with vigor in landraces genotypes.

This study quantified seed proteins of bean genotypes during different hydration times, in order to understand the process of protein mobilization and if there is a relationship between this biochemical component with seed vigor.

\section{MATERIALS AND METHODS}

\section{Seed material}

This study was conducted using seeds of eight landrace bean (Phaseolus vulgaris L.) genotypes (BAFs 07, 13, 23, 42, 44, 50, 55, 81) and two commercial cultivars (IPR-88-Uirapurú and Iapar 81) originally from the Bean Active Germplasm Bank (BAF) of the Santa Catarina State University. Genotypes underwent successive self-selection that favored greater homogeneity and stability within the population, having been previously characterized and studied in eight consecutive seasons. Seeds were produced in a field experiment conducted in a randomized complete block design during the agricultural season of 2012/2013 by conventional farming in Campos Novos, Santa Catarina. Harvested seeds were stored in a dry chamber at $10 \pm 2{ }^{\circ} \mathrm{C}$ and $50 \%$ relative humidity until analysis.

In a previous research, it was determined seed vigor differences by the accelerated aging test. Genotypes BAFs 13, 42, 55 and 81 had the highest physiological quality $(88,83,83$ and $87 \%$ ), whereas BAFs 07, 23, 44, $50(75,79,59$ and $78 \%)$ and the cultivars IPR-88-Uirapurú and Iapar 81 (75 and 73\%) had the lowest physiological quality (EHRHARDTBROCARDO \& COELHO, 2016).

This experiment was conducted in two investigations, according to the structure considered: whole-seed (embryonic axis, cotyledons and tegument) or cotyledons. In whole-seeds were quantified soluble protein (globulins) and soluble amino acid contents at hydration times $0,9,15,21$ and 27 hours. In cotyledons the determination of the content, profile analysis and characterization of soluble protein (globulins) were carried out, other hydration times were added (12 and 18 hours), most of which were included in phase II of hydration pattern.

Because in Arabidopsis seeds there have been change in gene expression as soon as $15 \mathrm{~min}$ after imbibition (PRESTON et al., 2009) and with rice seeds rapid changes in some metabolite levels had already occurred at $1 \mathrm{~h}$ after imbibition (HOWELL et al., 2008), the 0 and 9 hour points were evaluated.

Results of soluble protein and soluble amino acid content during the germination process, for each structure considered above, will be presented according radicle protrusion ( $\geq 50 \%$ seeds), 21 or 27 hydration hours (EHRHARDT-BROCARDO \& COELHO, 2016).

\section{Salt soluble protein (globulins) analysis \\ Extraction and quantification from whole-seeds}

The protein extraction procedure was described by LANDRY et al. (2000), using $1 \mathrm{~mL}$ of $0.5 \mathrm{M}$ Sodium Chloride $(\mathrm{NaCl}) \mathrm{pH} 2.4$ at $4{ }^{\circ} \mathrm{C}$. Whole-seeds were ground with liquid nitrogen prior to analysis. The extraction procedure was carried out twice, with three repetitions of $0.1 \mathrm{~g}$ seeds fine powder shaken for 1 minute in Vortex (AP56 - Phoenix), 30 minutes in orbital shaker table (Oxy304 - Oxylab) and centrifuged at $1500 \mathrm{~g}$ for 7 minutes (centrifuge CE01-B1 - Kacil), the supernatants were stored. The globulins content was determined as described by 
Bradford (1976) using bovine serum albumin (BSA) as a standard (BSA $0-1000 \mu \mathrm{g} \cdot \mathrm{mL}^{-1} ; \mathrm{y}=0.4039 \mathrm{x}+$ $\left.0.071, \mathrm{R}^{2}=0.9339\right)$. The reading was performed in a spectrophotometer (UV/VIS Spectro800S - Mars) with a wavelength of $595 \mathrm{~nm}$, and the concentration in $\mathrm{mg}$ protein. $\mathrm{mL}^{-1}$ protein extract.

\section{Extraction and quantification from cotyledons}

The protein extraction procedure was described by LANDRY et al. (2000), using $1 \mathrm{~mL}$ of $0.5 \mathrm{M}$ Sodium Chloride $(\mathrm{NaCl}) \mathrm{pH} 2.4$ at $4{ }^{\circ} \mathrm{C}$. Cotyledons samples were lyophilized prior to analysis. The extraction procedure was carried out twice, with three repetitions of $0.1 \mathrm{~g}$ cotyledons fine powder shaken for 1 minute in Vortex (AP56 - Phoenix), 30 minutes in orbital shaker table (Oxy304 - Oxylab) and centrifuged at $1500 \mathrm{~g}$ for 7 minutes (centrifuge CE01-B1 - Kacil), the supernatants were stored. Globulins content was determined as described by Bradford (1976) using bovine serum albumin (BSA) as a standard (BSA 0-1000 $\mu \mathrm{g} \cdot \mathrm{mL}^{-1} ; \mathrm{y}=0.4039 \mathrm{x}+$ $\left.0.071, \mathrm{R}^{2}=0.9339\right)$. The reading was performed in a spectrophotometer (UV/VIS Spectro800S - Mars) with a wavelength of $595 \mathrm{~nm}$, and the concentration in $\mathrm{mg}$ protein. $\mathrm{mL}^{-1}$ protein extract.

\section{Soluble amino acid analysis from whole-seeds}

The soluble amino acid extraction procedure was based on the extraction described by BIELESKI \& TURNER (1966), using $1 \mathrm{~mL}$ of MCW (methanol: chloroform: water, ratio 12:5:3). Whole-seeds were ground with liquid nitrogen prior to analysis. The extraction procedure was carried out with three repetitions of $0.1 \mathrm{~g}$ seeds fine powder. Samples were overnight at $4{ }^{\circ} \mathrm{C}$ and centrifuged at $1500 \mathrm{~g}$ for 30 minutes (centrifuge CE01-B1 - Kacil). In the supernatant was added $1 \mathrm{~mL}$ of chloroform and $1.5 \mathrm{~mL}$ of distilled water for each $4 \mathrm{~mL}$ of MCW used. Samples were centrifuged at $1500 \mathrm{~g}$ for 30 minutes again (centrifuge CE01-B1 - Kacil) and the aqueous phase was separated. This aliquot was placed in a water bath at $38{ }^{\circ} \mathrm{C}$ for 60 minutes. The soluble amino acid content was quantified using leucine as standard (0-200 nmol. $\mathrm{mL}^{-1} ; \mathrm{y}=209.05 \mathrm{x}-$ $\left.7.5566, \mathrm{R}^{2}=0.9919\right)$. The reading was performed in a spectrophotometer (UV/VIS Spectro800S - Mars) with a wavelength of $570 \mathrm{~nm}$, and the content in nmol.g ${ }^{-1}$ (seed fresh matter).

One-dimensional gel electrophoresis of cotyledons globulins

Electrophoretic analysis was carried out under denaturing condition (SDS-PAGE), in a mini vertical apparatus (K33-10V - Kasvi) with content of $12 \%$ (resolving gel) and $4 \%$ (stacking gel). The globulins, previously extracted, were applied to the gel according to LAEMMLI (1970). After quantification, $15 \mu \mathrm{g}$ of protein sample was dissolved in sample buffer composed of distilled water; Tris- $\mathrm{HCl} \mathrm{pH}$ 6.7; glycerol; $10 \%$ SDS (Sodium Dodecyl Sulfate); $0.5 \%$ bromophenol blue and 2-mercaptoethanol, with a ratio of 1:1. The electrophoresis system containing the samples was placed in $\mathrm{pH} 8.3$ buffer solution $(25 \mathrm{mM}$ Tris, $192 \mathrm{mM}$ glycine and 1\% SDS $10 \%$ ) for three hours at room temperature. After electrophoresis, the gels were washed with distilled water for complete buffer removal, and then, stained for 3 hours in Coomassie Brilliant Blue R-250. The evaluation procedure was carried out by comparing the samples protein profile with the molecular range marker (Precision Plus Protein ${ }^{\mathrm{TM}}$ - Bio-Rad, CA, USA). Reproducibility was confirmed by minimum of two repeats of each run of gel electrophoresis under similar electrophoretic conditions, and from two independent protein extractions. Subsequently, the digital documentation was carried out in transilluminator WL (DNR Bio-Imaging Systems Mini Bis Pro, Jerusalem - Israel) with Gel Capture software.

\section{Protein identification of cotyledons globulins} In-gel digestion of proteins, MALDI-ToF MS and MALDI-ToF/ToF analysis

Stained protein bands were individually excised from gel and submitted twice to a destaining procedure with a solution containing acetonitrile (50\%) and $25 \mathrm{mM}$ Ammonium Bicarbonate $\left(\mathrm{NH}_{4} \mathrm{HCO}_{3}\right)$ for 30 minutes at $25{ }^{\circ} \mathrm{C}$. The solution was replaced by pure acetonitrile and dried under vacuum (10 minutes). Excised bands were reduced and alkylated before digestion. Bands were kept on ice for 30 minutes with $20 \mathrm{ng}$. $\mu \mathrm{L}^{-1}$ trypsin (Trypsin Gold V5280 Promega) and $25 \mathrm{mM}$ Ammonium Bicarbonate $\left(\mathrm{NH}_{4} \mathrm{HCO}_{3}\right)$, then incubated at $37{ }^{\circ} \mathrm{C}$ for $14 \mathrm{~h}$. After digestion and extraction, peptides were mixed 1:1 with MALDI Matrix Solution (5 $\mu \mathrm{g} \cdot \mathrm{mL}^{-1} \quad \alpha$-cyano-4-hydroxycinnamic acid, $50 \%$ acetonitrile, and $0.1 \%$ trifluoroacetic acid), laid on a MTP 384 target plate (Bruker Daltonics, Germany) and dried at room temperature. Matrix-Assisted Laser Desorption/Ionization (MALDI) time-of-flight (ToF) Mass Spectrometry was used to get data for protein identification of tryptic-digested bands. MS and MS/MS spectra were obtained by Autoflex III MALDI-TOF Mass Spectrometer (Bruker Daltonics, Germany), that was carried out with full automatic mode using FlexControl Software version 3.3 (Bruker 
Daltonics, Germany) and the peak lists were created using FlexAnalysis Software version 3.0 (Bruker Daltonics, Germany).

The search in database was carried out by Mascot Software (Matrix Science; http://www. matrixscience.com) using P. vulgaris Database (downloaded from Phytozome - phaseolus 20160609) and Viridiplantae Database (SwissProt 2016_06). The following search parameters were used: (1) type of search: Peptide Mass Fingerprint; fixed modifications: carbamidomethylation of cysteine; variable modifications: methionine oxidation; mass values: monoisotopic; protein mass: unrestricted; peptide mass tolerance: $\pm 200 \mathrm{ppm}$; max missed cleavages: 1. (2) type of search: MS/MS Ion Search; fixed modifications: carbamidomethylation of cysteine; variable modifications: methionine oxidation; mass values: monoisotopic; protein mass: unrestricted; peptide mass tolerance: $\pm 2 \mathrm{Da}$; fragment mass tolerance: $\pm 0.7 \mathrm{Da}$; max missed cleavages: 1 . Universal Protein Resource Knowledge base (UniProt) (CONSORTIUM, 2017) database was used to access related biological function and description of proteins.

\section{Statistical analysis}

The experimental design was a completely randomized approach and analysis of variance (F Test) was performed. The Scott-Knott Test using Assistat (SILVA \& AZEVEDO, 2016) software grouped averages.

\section{RESULTS AND DISCUSSION}

Salt soluble protein (globulins) and soluble amino acid analysis from seeds

From the analysis of globulin content in whole-seeds during the germination process, it was observed that the seeds showed a behavior similar to that of hydration, where phase II finished between 21 and 27 hours, resulting on radicle protrusion (EHRHARDT-BROCARDO \& COELHO, 2016). Dry whole-seeds of all genotypes showed high globulins content, and during the first 9 hours of germination there was a significant decrease in this content (Table 1).

The first events caused by hydration are associated with damage repair accumulated during seed desiccation and storage, such as DNA repair. The formation of polysomes from free ribosomes occurs during early hydration, in order to create machinery for translation of mRNAs into proteins. Protein synthesis is initiated by pre-existing mRNA accumulated during seed development, however, this mRNA is degraded

Table 1 - Seed globulins content of landraces and commercial bean genotypes during germination process. Data are expressed as mg. $100 \mathrm{mg}^{-1}$ of seed fresh matter. The values are mean of three repetitions.

\begin{tabular}{|c|c|c|c|c|c|c|c|c|c|c|c|c|c|c|c|c|c|}
\hline \multirow{3}{*}{$\begin{array}{l}\text { Genotype } \\
07\end{array}$} & \multicolumn{15}{|c|}{ 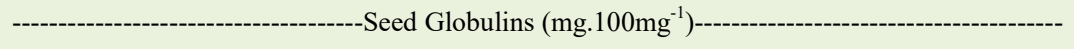 } & \multirow{3}{*}{$\begin{array}{l}\text { CV } \\
(\%)\end{array}$} & \multirow{3}{*}{$\begin{array}{c}\mathrm{F} \\
10.94^{* *}\end{array}$} \\
\hline & \multicolumn{3}{|c|}{--------0h-------- } & \multicolumn{3}{|c|}{-------9h--------- } & \multicolumn{3}{|c|}{-------15h-------- } & \multicolumn{3}{|c|}{--------21h-------- } & \multicolumn{3}{|c|}{-------27h-------- } & & \\
\hline & 6.30 & a & A & 3.80 & $\mathrm{a}$ & B & 5.55 & $\mathrm{a}$ & A & 5.58 & a & A & 5.94 & $\mathrm{a}$ & A & & \\
\hline 23 & 5.75 & $\mathrm{a}$ & A & 3.27 & b & B & 4.90 & $\mathrm{a}$ & A & 5.27 & $\mathrm{a}$ & A & 5.07 & b & A & 8.00 & $17.62^{* *}$ \\
\hline 44 & 5.66 & $\mathrm{a}$ & A & 3.23 & b & B & 5.56 & $\mathrm{a}$ & A & 5.32 & $\mathrm{a}$ & A & 5.18 & b & A & 12.97 & $7.22^{* *}$ \\
\hline 50 & 5.72 & $\mathrm{a}$ & A & 3.28 & b & B & 4.96 & $\mathrm{a}$ & A & 5.17 & $\mathrm{a}$ & A & 5.03 & $\mathrm{~b}$ & A & 7.81 & $17.82^{* *}$ \\
\hline 13 & 6.12 & $\mathrm{a}$ & A & 2.73 & d & B & 5.17 & $\mathrm{a}$ & A & 5.44 & $\mathrm{a}$ & A & 5.63 & $\mathrm{a}$ & A & 8.09 & $31.92^{* *}$ \\
\hline 42 & 6.90 & $\mathrm{a}$ & A & 2.53 & d & $\mathrm{C}$ & 5.20 & $\mathrm{a}$ & B & 4.62 & b & B & 5.22 & b & B & 6.65 & $70.26^{* *}$ \\
\hline 55 & 6.73 & $\mathrm{a}$ & A & 3.16 & b & $\mathrm{C}$ & 5.40 & $\mathrm{a}$ & B & 5.16 & $\mathrm{a}$ & B & 4.65 & b & B & 8.27 & $29.12^{* *}$ \\
\hline 81 & 6.65 & $\mathrm{a}$ & A & 2.92 & $\mathrm{c}$ & $\mathrm{C}$ & 5.54 & $\mathrm{a}$ & B & 5.64 & $\mathrm{a}$ & B & 5.15 & $\mathrm{~b}$ & B & 6.84 & $45.40^{* *}$ \\
\hline IPR-88-Uirapurú & 5.88 & a & A & 3.05 & $\mathrm{c}$ & $\mathrm{C}$ & 5.29 & $\mathrm{a}$ & A & 4.75 & $\mathrm{~b}$ & B & 5.59 & a & A & 7.47 & $28.09^{* *}$ \\
\hline Iapar 81 & 5.39 & $\mathrm{a}$ & A & 3.40 & $\mathrm{~b}$ & B & 5.60 & $\mathrm{a}$ & A & 4.70 & $\mathrm{~b}$ & A & 5.11 & $\mathrm{~b}$ & A & 12.84 & $5.92^{*}$ \\
\hline CV $(\%)$ & 12.56 & & & 4.84 & & & 7.65 & & & 6.11 & & & 7.40 & & & & \\
\hline $\mathrm{F}$ & 1.36 & ns & & 16.52 & ** & & 1.19 & ns & & 3.97 & ** & & 2.65 & * & & & \\
\hline
\end{tabular}

Mean values followed by the same letter do not differ according to the Scott-Knott Test, lowercase in column and uppercase in row. ${ }^{* *}$ significative at $1 \%(\mathrm{P}<0.01) ;{ }^{*}$ significative at $5 \%(0.01 \leq \mathrm{P}<0.05)$; ns non-significant $(\mathrm{P} \geq 0.05)$. 
and protein synthesis becomes dependent on newly synthesized mRNA during hydration (BEWLEY \& BLACK, 1994). De novo synthesis is essential because total soluble amino acids are not enough to proteins formation during germination, so, the degradation of seed storage proteins begins on first hours of hydration (BEWLEY et al., 2013), demonstrated by decrease in soluble protein content of bean seeds. Seed storage proteins are main source of amino acids during early germination and are important for energy production (ANGELOVICI et al., 2011).

After 9 hours of germination, genotypes showed an increase in globulin content, as a result of respiration and metabolism reactivation, and protein synthesis intensification to initiate embryonic axis growth and further radicle protrusion. From the increase in globulin content (15 hours), other hydration times presented constant contents equal to the initial content ( 0 hour), except for genotypes 42, 55 and 81, which increased their protein content but did not achieve the high content as shown in dry whole-seed (Table 1).

The genotypes showed no difference in globulin content at hydration times of 0 and 15 hours. In 21 hours of hydration, genotypes with the lowest globulin content were 42 and commercial cultivars IPR-88-Uirapurú and Iapar 81. In 27 hours of hydration, genotypes 07 and 13 and the commercial cultivar IPR-88-Uirapurú showed the highest globulin content (Table 1).

From the vigor data presented in EHRHARDT-BROCARDO \& COELHO (2016), genotypes 42 and commercial cultivar IPR-88Uirapurú had high conversion efficiency of their reserves for normal seedling formation (percentage of reserves mobilization), characterizing its high physiological potential. Because these genotypes seeds had high initial globulins content (Table 1), that provided proteins for hydrolysis in amino acids, and also, the efficiency of this hydrolysis allowing a high content of amino acids in 9 and 15 hours (Table 2), a lower soluble protein content was required at the time of radicle protrusion in 21 hours (Table 1).

The soluble amino acids content in landrace genotypes and in commercial cultivar IPR-88-Uirapurú increased in the first 9 hours of hydration (Table 2) as a function of decrease in salt soluble protein content (globulins) (Table 1). When

Table 2 - Seed soluble amino acid content of landraces and commercial bean genotypes during germination process. Data are expressed as nmol.g $\mathrm{g}^{-1}$ of seed fresh matter. The values are mean of three repetitions.

\begin{tabular}{|c|c|c|c|c|c|c|c|c|c|c|c|c|c|c|c|c|c|}
\hline \multirow{3}{*}{$\begin{array}{l}\text { Genotype } \\
07\end{array}$} & \multicolumn{15}{|c|}{ 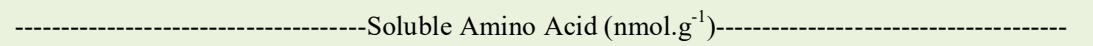 } & \multirow{3}{*}{$\begin{array}{l}\text { CV } \\
(\%)\end{array}$} & \multirow{3}{*}{$\begin{array}{c}\mathrm{F} \\
6.01^{* *}\end{array}$} \\
\hline & \multicolumn{3}{|c|}{---------0h-------- } & \multicolumn{3}{|c|}{---------9h--------- } & \multicolumn{3}{|c|}{--------15h------- } & \multicolumn{3}{|c|}{--------21h-------- } & \multicolumn{3}{|c|}{--------27h-------- } & & \\
\hline & 7.41 & $\mathrm{a}$ & B & 7.52 & $\mathrm{c}$ & A & 7.59 & $\mathrm{c}$ & A & 7.54 & $\mathrm{a}$ & A & 7.50 & a & A & & \\
\hline 23 & 7.42 & $\mathrm{a}$ & B & 7.53 & $\mathrm{c}$ & A & 7.54 & $\mathrm{c}$ & A & 7.49 & $\mathrm{a}$ & A & 7.44 & $\mathrm{~b}$ & B & 0.49 & $6.21^{* *}$ \\
\hline 44 & 7.26 & $\mathrm{~b}$ & B & 7.47 & $\mathrm{c}$ & A & 7.45 & $\mathrm{c}$ & A & 7.50 & a & A & 7.46 & $\mathrm{a}$ & A & 0.64 & $12.07^{* *}$ \\
\hline 50 & 7.47 & $\mathrm{a}$ & $\mathrm{B}$ & 7.72 & $\mathrm{~b}$ & A & 7.56 & $\mathrm{c}$ & $\mathrm{B}$ & 7.44 & $\mathrm{~b}$ & $\mathrm{~B}$ & 7.51 & a & B & 0.71 & $12.40^{* *}$ \\
\hline 13 & 7.40 & $\mathrm{a}$ & B & 7.63 & $\mathrm{c}$ & A & 7.57 & $\mathrm{c}$ & A & 7.40 & $\mathrm{c}$ & B & 7.56 & a & A & 0.79 & $9.50^{* *}$ \\
\hline 42 & 7.49 & a & $\mathrm{B}$ & 7.84 & $\mathrm{a}$ & A & 7.79 & $\mathrm{a}$ & A & 7.36 & $\mathrm{c}$ & $\mathrm{B}$ & 7.39 & $\mathrm{~b}$ & $\mathrm{~B}$ & 1.03 & $25.35^{* *}$ \\
\hline 55 & 7.34 & $\mathrm{~b}$ & $\mathrm{C}$ & 7.72 & $\mathrm{~b}$ & A & 7.52 & $\mathrm{c}$ & B & 7.34 & $\mathrm{c}$ & $\mathrm{C}$ & 7.39 & $\mathrm{~b}$ & $\mathrm{C}$ & 0.73 & $26.78^{* *}$ \\
\hline 81 & 7.37 & $\mathrm{~b}$ & $\mathrm{D}$ & 7.84 & $\mathrm{a}$ & A & 7.61 & c & B & 7.31 & $\mathrm{c}$ & $\mathrm{D}$ & 7.53 & $\mathrm{a}$ & $\mathrm{C}$ & 0.58 & $68.21^{* *}$ \\
\hline IPR-88-Uirapurú & 7.44 & $\mathrm{a}$ & $\mathrm{C}$ & 7.88 & a & A & 7.67 & b & B & 7.32 & $\mathrm{c}$ & $\mathrm{D}$ & 7.49 & a & $\mathrm{C}$ & 0.57 & $74.21^{* *}$ \\
\hline Iapar 81 & 7.33 & b & A & 7.50 & $\mathrm{c}$ & A & 7.57 & $\mathrm{c}$ & A & 7.42 & $\mathrm{~b}$ & A & 7.47 & a & A & 1.26 & $2.64 \mathrm{~ns}$ \\
\hline CV (\%) & 0.64 & & & 1.03 & & & 0.88 & & & 0.53 & & & 0.67 & & & & \\
\hline F & 6.68 & ** & & 11.72 & ** & & 5.72 & ** & & 11.93 & ** & & 3.66 & ** & & & \\
\hline
\end{tabular}

Mean values followed by the same letter do not differ according to the Scott-Knott Test, lowercase in column and uppercase in row. ${ }^{* *}$ significant at $1 \%(\mathrm{P}<0.01)$; ns non-significant $(\mathrm{P} \geq 0.05)$. 
embryonic axis is growing, soluble protein content decreases and soluble amino acid content increases, this is in function of protein catabolism that releases its constituent amino acids. The hydrolysis is carried by proteases classified according to hydrolytic activity. Some amino acids are converted to amides (glutamine and asparagine) and are transported to the growing embryonic axis. In addition to increasing the soluble amino acids content from protein degradation (SATYANARAYANA et al., 2011), biosynthesis of novel amino acids is required for production of developmental regulatory compounds (ALENCAR et al., 2012; BUCKERIDGE et al., 2004).

From the seed vigor data by accelerated aging test (EHRHARDT-BROCARDO \& COELHO, 2016), high vigor genotypes $(13,42,55$ and 81$)$ and commercial cultivar IPR-88-Uirapurú presented low soluble amino acid content at the moment of radicle protrusion (21 hours) (Table 2). In contrast, low vigor genotypes $(07,23,44,50$ and Iapar 81) showed high soluble amino acid content at the time of radicle protrusion (21 hours: 23 and 50 or 27 hours: 07, 44 and Iapar 81) (Table 2).
With the whole seed, the purpose was to verify differences between genotypes. However, the soluble proteins (globulins), even with differences in content, maintained the same behavior among the genotypes, according to the triphasic hydration pattern. Thus, another strategy was necessary to characterize the proteins according to the vigor: to separate structures of seed (cotyledons and embryonic axis) and to include more intervals of analysis in hydration times.

Salt soluble protein (globulins) analysis from cotyledons

By the data of globulin content in cotyledons during germination process, most genotypes increased the availability of salt soluble proteins (globulins) (Table 3), this is a result of protein hydrolysis intensification to initiate the growth of embryonic axis and posterior radicle protrusion.

All genotypes showed a significant change in globulin content during germination, some increased $(42,81$ and IPR-88-Uirapurú) and others increased and decreased $(07,23,44,50,13,55$ e Iapar 81).

Table 3 - Cotyledons globulins content of landraces and commercial bean genotypes during germination process. Data are expressed as mg. $100 \mathrm{mg}^{-1}$ of cotyledons dry matter. The values are mean of three repetitions.

\begin{tabular}{|c|c|c|c|c|c|c|c|c|c|c|c|c|c|c|c|c|c|c|c|c|c|c|c|}
\hline \multirow{3}{*}{$\begin{array}{l}\text { Genotype } \\
07\end{array}$} & \multicolumn{21}{|c|}{ - } & \multirow{3}{*}{$\begin{array}{c}\text { CV (\%) } \\
4.99\end{array}$} & \multirow{2}{*}{$\mathrm{F}$} \\
\hline & \multicolumn{3}{|c|}{------0h------- } & \multicolumn{3}{|c|}{-----9h------ } & \multicolumn{3}{|c|}{-----12h----- } & \multicolumn{3}{|c|}{----15h---- } & \multicolumn{3}{|c|}{-----18h---- } & \multicolumn{3}{|c|}{-----21h----- } & \multicolumn{3}{|c|}{-------27h------ } & & \\
\hline & 5.08 & $\mathrm{~b}$ & $\mathrm{C}$ & 4.97 & $\mathrm{e}$ & $\mathrm{C}$ & & - & & 4.48 & $\mathrm{c}$ & $\mathrm{D}$ & 6.20 & $\mathrm{c}$ & B & 6.27 & $\mathrm{c}$ & B & 7.43 & a & A & & $43.52^{* *}$ \\
\hline 23 & 5.15 & $\mathrm{~b}$ & $\mathrm{D}$ & 5.72 & d & $\mathrm{C}$ & 4.50 & $\mathrm{c}$ & $\mathrm{F}$ & 4.73 & $\mathrm{c}$ & $\mathrm{E}$ & 6.51 & $\mathrm{c}$ & B & 7.40 & $\mathrm{a}$ & A & & - & & 1.94 & $306.87^{* *}$ \\
\hline 44 & 4.62 & $\mathrm{c}$ & $\mathrm{D}$ & 6.57 & b & B & & - & & 5.88 & $\mathrm{~b}$ & $\mathrm{C}$ & 7.14 & $\mathrm{a}$ & A & 5.75 & $\mathrm{c}$ & $\mathrm{C}$ & 5.43 & $\mathrm{~b}$ & $\mathrm{C}$ & 4.09 & $39.79^{* *}$ \\
\hline 50 & 5.02 & $\mathrm{~b}$ & $\mathrm{D}$ & 5.98 & $\mathrm{c}$ & $\mathrm{C}$ & 4.92 & $\mathrm{c}$ & $\mathrm{D}$ & 4.74 & $\mathrm{c}$ & $\mathrm{D}$ & 6.75 & $\mathrm{~b}$ & $\mathrm{BC}$ & 7.55 & $\mathrm{a}$ & A & & - & & 4.90 & $47.83^{* *}$ \\
\hline 13 & 4.42 & $\mathrm{c}$ & $\mathrm{C}$ & 5.50 & d & B & 4.76 & $\mathrm{c}$ & $\mathrm{C}$ & 5.44 & $\mathrm{~b}$ & B & 6.80 & $\mathrm{~b}$ & A & 6.96 & $\mathrm{~b}$ & A & & - & & 3.48 & $83.87^{* *}$ \\
\hline 42 & 5.00 & $\mathrm{~b}$ & $\mathrm{D}$ & 5.01 & e & $\mathrm{D}$ & 4.73 & $\mathrm{c}$ & D & 5.61 & $\mathrm{~b}$ & $\mathrm{C}$ & 6.24 & $\mathrm{c}$ & B & 6.97 & $\mathrm{~b}$ & A & & - & & 3.35 & $63.75^{* *}$ \\
\hline 55 & 4.94 & b & $\mathrm{C}$ & 6.71 & $\mathrm{~b}$ & B & 6.39 & a & B & 6.62 & a & B & 7.28 & a & A & 6.83 & b & B & & - & & 4.26 & $25.50^{* *}$ \\
\hline 81 & 5.02 & $\mathrm{~b}$ & $\mathrm{C}$ & 5.04 & e & $\mathrm{C}$ & 4.80 & $\mathrm{c}$ & $\mathrm{C}$ & 5.52 & $\mathrm{~b}$ & B & 6.73 & b & A & 6.82 & b & A & & - & & 3.62 & $57.96^{* *}$ \\
\hline $\begin{array}{l}\text { IPR-88- } \\
\text { Uirapurú }\end{array}$ & 4.55 & $\mathrm{c}$ & $\mathrm{C}$ & 4.97 & e & $\mathrm{C}$ & 5.57 & $\mathrm{~b}$ & B & 5.31 & $\mathrm{~b}$ & B & 6.80 & $\mathrm{~b}$ & A & 6.64 & $\mathrm{~b}$ & A & & - & & 5.39 & $26.65^{* *}$ \\
\hline Iapar 81 & 5.53 & $\mathrm{a}$ & $\mathrm{D}$ & 7.66 & $\mathrm{a}$ & A & & - & & 7.01 & $\mathrm{a}$ & B & 6.35 & $\mathrm{c}$ & $\mathrm{C}$ & 6.69 & b & B & 5.58 & b & $\mathrm{D}$ & 5.45 & $16.56^{* *}$ \\
\hline CV (\%) & 2.97 & & & 3.46 & & & 4.68 & & & 5.41 & & & 4.14 & & & 4.65 & & & 3.89 & & & & \\
\hline $\mathrm{F}$ & 14.87 & ** & & 62.41 & ** & & 22.97 & ** & & 22.01 & $* *$ & & 5.08 & ** & & 7.98 & ** & & 64.70 & ** & & & \\
\hline
\end{tabular}

Mean values followed by the same letter do not differ according to the Scott-Knott Test, lowercase in column and uppercase in row. **significant at $1 \%(\mathrm{P}<0.01)$. 
From the seed vigor data by accelerated aging test (EHRHARDT-BROCARDO \& COELHO, 2016), high vigor genotypes $(13,42,55$ and 81) and commercial cultivar IPR-88-Uirapurú presented low globulins content in cotyledons at the moment of radicle protrusion (21 hours) (Table 3 ). In contrast, some low vigor genotypes $(07,23$ and 50) showed high globulins content in cotyledons at the moment of radicle protrusion (21 hours: 23 and 50 or 27 hours: 07) (Table 3).

These globulins data from cotyledons indicate that; although, high vigor genotypes provided higher protein content throughout germination process, at specific time of radicle protrusion, they hydrolyzed soluble proteins more rapidly into amino acids, mobilizing them to growth points in relation to low vigor genotypes. Thus, high vigor genotypes showed greater efficiency in hydrolysis and mobilization of protein component.

\section{One-dimensional gel electrophoresis of cotyledons globulins}

For analysis of electrophoretic globulins profile, bands were observed according to difference of intensity between genotypes before hydration, because there was not change of bands in gels throughout germination process $(0,9,12,15,18$, 21 and 27 hours). From analysis of electrophoretic globulins profile (Figure 1), landraces genotypes and commercial cultivars showed bands ranging from 15 to $150 \mathrm{kDa}$, with higher intensity bands in molecular masses between 37 and $50 \mathrm{kDa}$.

In electrophoretic globulins profile, genotypes 07,44 and the commercial cultivar Iapar 81 showed differences of intensity in one of the bands $(25 \mathrm{kDa})$ in relation to other genotypes (Figure 2). It corresponds to a protein that could be involved with the longest time necessary for radicular protrusion or with the low vigor observed in these genotypes (EHRHARDT-BROCARDO \& COELHO, 2016).

The analysis of electrophoretic profile did not allow to associate differential detection (presence/absence) of protein bands with vigor differences among genotypes. However, considering only genotypes with radicle protrusion at 21 hours, the difference in band intensity could be associated with physiological quality. High vigor genotypes (13,

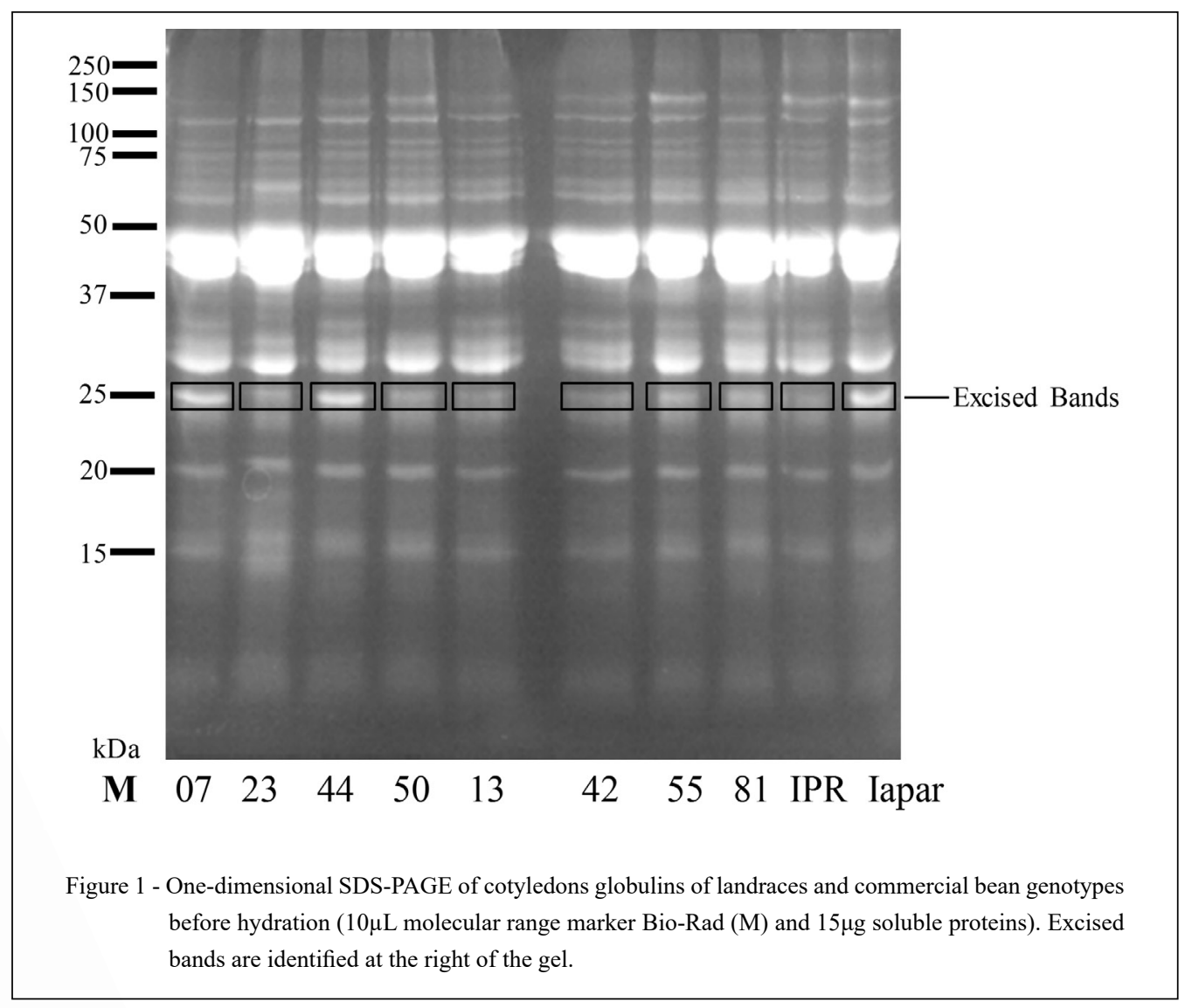

Ciência Rural, v.52, n.2, 2022. 
42, 55 and 81) showed similar band intensity peaks, particularly 55 and 81 , and different in relation to low vigor genotypes (23 and 50).

\section{Protein identification of cotyledons globulins}

Proteins from landraces and commercial bean genotypes were extracted and then separated by 1D SDS-PAGE, followed by protein identification using mass spectrometry tools, Universal Protein Knowledgebase (UniProtKB) and SwissProt databases.

After image analysis, each intense Coomassie staining lane of the gel was divided into approximately $2.5 \mathrm{~mm}$ slices; the slices were then subjected to in-gel proteolysis with trypsin. A protein was identified from bands in 1D SDS-PAGE
(Figure 1) that it showed differences of intensity in genotypes 07, 44 and the commercial cultivar Iapar 81 in relation to other genotypes (Figure 2). This protein is "Alpha-Amylase Inhibitor" that presents a length of 262 amino acids and it has as molecular functions: alpha-amylase inhibitor activity (stops, prevents or reduces the activity of alpha-amylase) and carbohydrate binding.

The analysis of the electrophoretic pattern of seed storage proteins in soybean proved to be a very stable tool in the characterization of cultivars (VIEIRA et al., 2009). However, characterization of genotypes based only on differential detection and band intensity is a method susceptible to misleading comparisons, since bands may be the result of protein groups, not

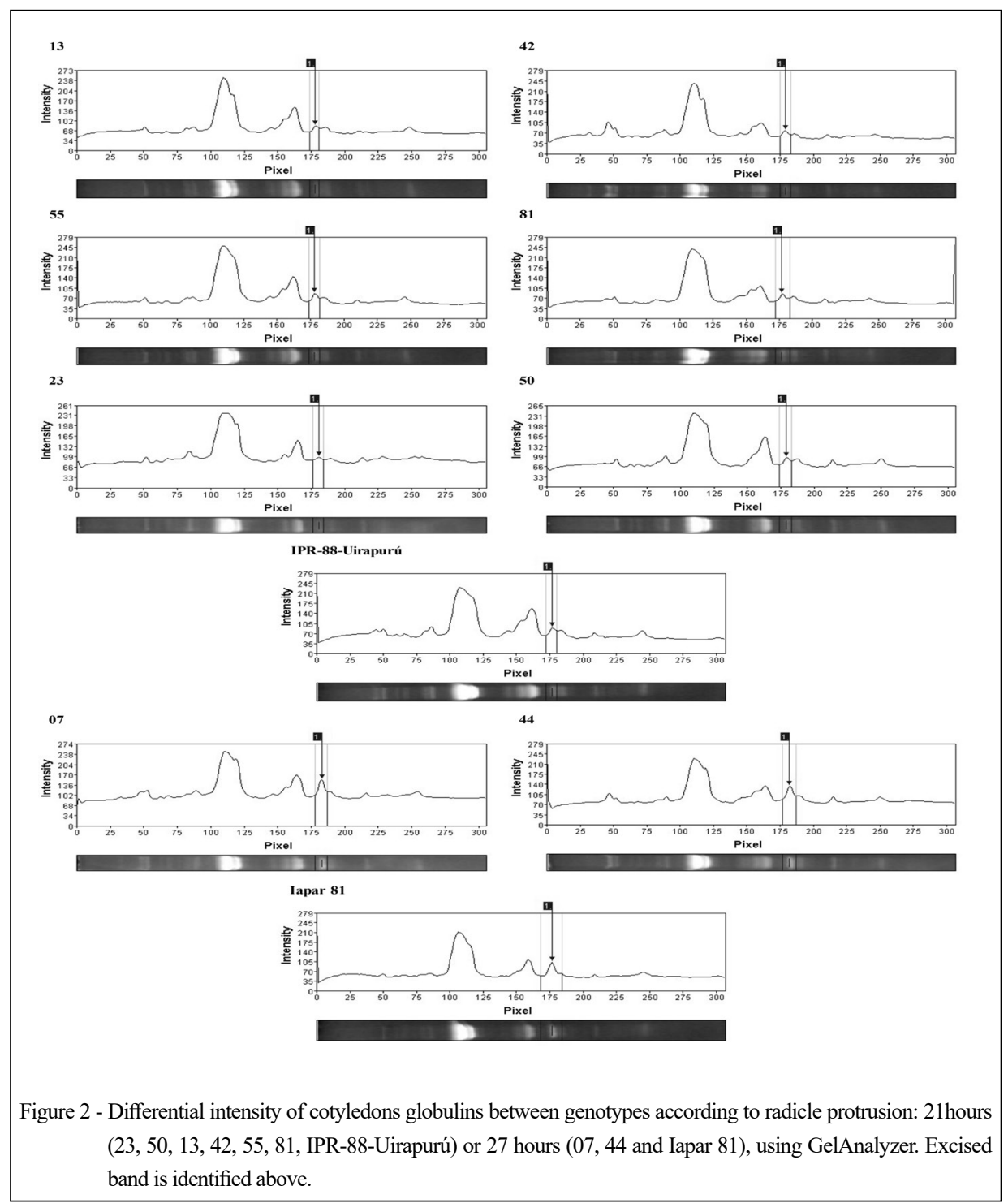

Ciência Rural, v.52, n.2, 2022. 
just a specific protein. Thus, for this investigation, it was considered impracticable to determine and clarify the genetic diversity between the genotypes for the normal and vigor seedling formation only through the analysis of the electrophoretic profile. From the mass spectrometry technology, it was possible to identify at least one protein that is present in the band with differential intensity in the low vigor genotypes, the alpha-amylase inhibitor.

In YANG et al. (2007) and HE \& YANG (2013), the enzyme $\alpha$-amylase was sharply increased during germination, and this protein was suggested as a possible ideal candidate biomarker for rice seed germination. But, in the present study, the protein "Alpha-Amylase Inhibitor", observed in all genotypes, can be involved with the longer time needed for radicle protrusion, because it showed differences of intensity in genotypes 07, 44 and the commercial cultivar Iapar 81 in relation to other genotypes.

Since the seed vigor is a complex property that determines its potential for rapid uniform emergence and development under a wide range of field conditions (RAJJOU et al., 2012), the longer time to radicle protrusion may affect the performance of seeds in the field, compromising the speed and uniformity of seedling emergence and crop establishment. This may be demonstrated, because in the emergence of seedlings, when reduced and/ or non-uniform, may delay development, cause nonuniformity of crop at different phenological stages, interfere in product quality and plant characteristics related to crop efficiency (plant height, ramification intensity, fruit insertion height, stem diameter and lodging intensity) (MARCOS-FILHO, 2015). Moreover, the higher rates of growth in initial period ensure greater and more rapid closure of the soil surface, providing lower evaporation and higher water use and increased competitive capacity, benefiting weed control (DUTRA \& TEÓFILO, 2007; HENNING et al., 2010).

\section{CONCLUSION}

The high vigor genotypes showed greater efficiency in hydrolysis and mobilization of protein component, because they presented low globulins content in cotyledons at the moment of radicle protrusion in relation to low vigor genotypes. Once identified, the protein alpha-amylase inhibitor, observed in all genotypes, is involved with the longer time needed for radicle protrusion, because it showed differences of intensity in genotypes 07,44 and the commercial cultivar Iapar 81 in relation to other genotypes.

\section{ACKNOWLEDGEMENTS}

The authors acknowledge the Coordenação de Aperfeiçoamento de Pessoal de Nível Superior (CAPES), Conselho Nacional de Desenvolvimento Científico e Tecnológico (CNPq), Fundação de Amparo à Pesquisa e Inovação de Santa Catarina (FAPESC) and Programa de Apoio a Pesquisa (PAP) of Universidade do Estado de Santa Catarina (UDESC) together FAPESC (TR653PAP/UDESC/FAPESC) for providing financial support for developing this study and corresponding author (Coelho, C.M.M.) thanks CNPq for productivity scholarship. The authors also acknowledge Centro de Biologia Molecular Estrutural of Universidade Federal de Santa Catarina (CEBIME-UFSC) for Mass Spectrometry facilities, where part of the work was developed.

\section{DECLARATION OF CONFLICT OF INTEREST}

The authors declare no conflict of interest.

\section{AUTHORS' CONTRIBUTIONS}

N.C.M.E-B. conducted the research project, sample preparation for biochemical investigations, statistical analyses, elaboration of the results and wrote the manuscript. C.M.M.C. guided the planning of the research project, contributed to the discussion and revised the manuscript. All authors critically revised the manuscript and approved of the final version.

\section{REFERENCES}

ALENCAR, N.L.M. et al. Seed reserve composition and mobilization during germination and early seedling establishment of Cereus jamacaru D. C. ssp. jamacaru (Cactaceae). Anais da Academia Brasileira de Ciências, v.84, p.823-832, 2012. Available from: $<$ https://doi. org/10.1590/S0001-37652012000300024>. Accessed: Feb. 15, 2020.

ANGELOVICI, R. et al. A seed high-lysine trait is negatively associated with the TCA cycle and slows down Arabidopsis seed germination. New Phytologist, v.189, p.148-159, 2011. Available from: $<$ https://doi. org/10.1111/j.1469-8137.2010.03478.x>. Accessed: Feb. 15, 2020.

BEWLEY, J. Seed germination and dormancy. The Plant Cell, v.9, p.1055-1066, 1997. Available from: <https://doi.org/10.1105/ tpc.9.7.1055>. Accessed: Feb. 15, 2020.

BEWLEY, J.; BLACK, M. Seeds: physiology of development and germination, 2nd ed. New York, 1994.

BEWLEY, J. et al. Seeds: physiology of development, germination and dormancy, 3rd ed. New York, 2013.

BIELESKI, R.; TURNER, N. Separation and estimation of amino acids in crude plant extracts by thin-layer electrophoresis and chromatography. Analytical Biochemistry, v.17, p. 278-293, 1966. Available from: $<$ https://doi.org/10.1016/0003-2697(66)90206-5>. Accessed: Feb. 15, 2020.

BRADFORD, M.M. A rapid and sensitive method for the quantitation of microgram quantities of protein utilizing the principle of protein-dye binding. Analytical Biochemistry, v.72, p.248-254, 1976. Available from: <https://doi.org/10.1016/00032697(76)90527-3>. Accessed: Feb. 15, 2020. 
BUCKERIDGE, M. et al. Mobilização de reservas, In: FERREIRA, A.G.; BORGHETTI, F. (Org.). Germinação: do básico ao aplicado. Porto Alegre: Artmed, p.163-185, 2004.

CHÉREAU, D. et al. Combination of existing and alternative technologies to promote oilseeds and pulses proteins in food applications. Oilseeds Fats Crops and Lipids, v.23, n.4, 2016. Available from: $<$ https://doi.org/10.1051/ocl/2016020>. Accessed: Feb. 15, 2020.

CONSORTIUM, U. UniProt: the universal protein knowledgebase. Nucleic Acids Research, v.45, p.D158-D169, 2017. Available from: $<$ https://doi.org/10.1093/nar/gkh131>. Accessed: Feb. 15, 2020.

DUTRA, A.; TEÓFILO, E. Accelerated aging to assess seed vigor of cowpea. Revista Brasileira de Sementes, v.29, p.193197, 2007. Available from: <https://doi.org/10.1590/S010131222007000100027>. Accessed: Feb. 15, 2020

EHRHARDT-BROCARDO, N.C.M.; COELHO, C.M.M. Hydration patterns and physiologic quality of common bean seeds. Semina: Ciências Agrárias, v.37, p.1791-1800, 2016. Available from: <https:// doi.org/10.5433/1679-0359.2016v37n4p1791>. Accessed: Feb. 15, 2020

ERBAŞ, S. et al. A. Mobilization of seed reserves during germination and early seedling growth of two sunflower cultivars. Journal of Applied Botany and Food Quality, v.89, p.217-222, 2016. Available from: <https://doi.org/10.5073/ JABFQ.2016.089.028>. Accessed: Feb. 15, 2020.

FREITAS, R. et al. Use of a single method in the extraction of the seed storage globulins from several legume species. Application to analyse structural comparisons within the major classes of globulins. International Journal of Food Sciences and Nutrition, v.51, p.341-352, 2000. Available from: <https://doi. org/10.1080/096374800426939>. Accessed: Feb. 15, 2020.

GOYOAGA, C. et al. Content and distribution of protein, sugars and inositol phosphates during the germination and seedling growth of two cultivars of Vicia faba. Journal of Food Composition and Analysis, v.24, p.391-397, 2011. Available from: <https://doi. org/10.1016/j.jfca.2010.11.002>. Accessed: Feb. 15, 2020

GU, J. et al. Proteomic dissection of seed germination and seedling establishment in Brassica napus. Frontiers in Plant Science, v.7, p.1-19, 2016. Available from: <https://doi.org/10.3389/ fpls.2016.01482>. Accessed: Feb. 15, 2020.

HAN, C. et al. Analysis of proteome profile in germinating soybean seed, and its comparison with rice showing the styles of reserves mobilization in different crops. PLoS ONE, v.8, e56947, 2013. Available from: <https://doi.org/10.1371/journal.pone.0056947>. Accessed: Feb. 15, 2020

HE, D.; YANG, P. Proteomics of rice seed germination. Frontiers in Plant Science, v.4, p.1-9, 2013. Available from: $<$ https://doi. org/10.3389/fpls.2013.00246>. Accessed: Feb. 15, 2020.

HENNING, F.A. et al. Composição química e mobilização de reservas em sementes de soja de alto e baixo vigor. Bragantia, v.69, p.727-733, 2010. Available from: <https://doi.org/10.1590/ S0006-87052010000300026>. Accessed: Feb. 15, 2020.

HOWELL, K.A. et al. Mapping metabolic and transcript temporal switches during germination in rice highlights specific transcription factors and the role of RNA instability in the germination process. Plant Physiology, v.149, p.961-980,
2008. Available from: <https://doi.org/10.1104/pp.108.129874>. Accessed: Feb. 15, 2020.

LAEMMLI, U. Cleavage of structural proteins during the assembly of the head of bacteriophage T4. Nature, v.227, p.680-685, 1970. Available from: < https://doi.org/10.1038/227680a0>. Accessed: Feb. 15, 2020.

LANDRY, J. et al. Improved method for isolating and quantitating $\alpha$-amino nitrogen as nonprotein, true protein, salt-soluble proteins, zeins, and true glutelins in maize endosperm. Cereal Chemistry, v.77, p.620-626, 2000. Available from: <https://doi.org/10.1094/ CCHEM.2000.77.5.620>. Accessed: Feb. 15, 2020

LOPES, L.D.S. et al. Mobilisation of reserves during germination of Jatropha seeds. Revista Ciência Agronômica, v.44, p.371378, 2013. Available from: <https://doi.org/10.1590/S180666902013000200021>. Accessed: Feb. 15, 2020.

MARCOS-FILHO, J. Fisiologia de sementes de plantas cultivadas, 2nd ed. ABRATES, Londrina, 2015.

MÜNTZ, K et al. Stored proteinases and the initiation of storage protein mobilization in seeds during germination and seedling growth. Journal of Experimental Botany, v.52, p.1741-1752, 2001. Available from: <https://doi.org/10.1093/ jexbot/52.362.1741>. Accessed: Feb. 15, 2020.

OSBORNE, T.B. The vegetable proteins, 2nd ed. London, 1924

PRESTON, J. et al. Temporal expression patterns of hormone metabolism genes during imbibition of Arabidopsis thaliana seeds: a comparative study on dormant and non-dormant accessions. Plant Cell Physiology, v.50, p.1786-1800, 2009. Available from: $<$ https://doi.org/10.1093/pcp/pcp121>. Accessed: Feb. 15, 2020.

RAJJOU, L. et al. Seed germination and vigor. Annual Review of Plant Biology, v.63, p. 507-533, 2012. Available from: <https:// doi.org/10.1146/annurev-arplant-042811-105550>. Accessed: Feb. 15,2020 .

ROSENTAL, L. et al. Activation and regulation of primary metabolism during seed germination. Seed Science Research, v.24, p.1-15, 2014. Available from: <https://doi.org/10.1017/ S0960258513000391>. Accessed: Feb. 15, 2020

SATYANARAYANA, B. et al. Biochemical changes during seed germination of Sterculia urens Roxb. Notulae Scientia Biologicae, v.3, p.105-108, 2011. Available from: <https://doi.org/10.15835/ nsb336116>. Accessed: Feb. 15, 2020.

SILVA, F. de A.S.; AZEVEDO, C.A.V. The Assistat software version 7.7 and its use in the analysis of experimental data. African Journal of Agricultural Research, v.11, p.3733-3740, 2016. Available from: <https://doi.org/10.5897/AJAR2016.11522>. Accessed: Feb. 15, 2020.

VIEIRA, E. et al. Soybean cultivar characterization using morphological descriptors and protein and isoenzyme biochemical markers. Revista Brasileira de Sementes, v.31, p.86-94, 2009. Available from: <https://doi.org/10.1590/S010131222009000100010>. Accessed: Feb. 15, 2020.

YANG, P. et al. Proteomic analysis of rice (Oryza sativa) seeds during germination. Proteomics, v.7, p.3358-3368, 2007. Available from: <https://doi.org/10.1002/pmic.200700207>. Accessed: Feb. 15, 2020.

Ciência Rural, v.52, n.2, 2022. 